\title{
Mechanisms and Influencing Factors of Electro-Kinetic Enhanced Phytoextraction for the Recovery of Metal-Polluted Soils
}

\author{
Xinyu Mao ${ }^{1,2^{*}}$, Xu Yang ${ }^{1,2}$, Hengji Qin ${ }^{1,2}$, Xiaohou Shao ${ }^{1,2}$, Zhanyu Zhang ${ }^{1,2}$ and Jing $\mathbf{L i}^{1,2}$ \\ ${ }^{1}$ College of Agricultural Engineering, Hohai University, Nanjing 210098, China \\ ${ }^{2}$ Key Laboratory of Efficient Irrigation-Drainage and Agricultural Soil-Water Environment in Southern China, Ministry of Education, Nanjing 210098, China \\ "Corresponding author: Xinyu Mao, College of Agricultural Engineering, Hohai University, Nanjing 210098, China, Tel: +02583786395; E-mail: mxy880731@163.com
}

Received: September 26, 2018; Accepted: October 02, 2018; Published: October 28, 2018

Copyright: (c) 2018 Mao X, et al. This is an open-access article distributed under the terms of the Creative Commons Attribution License, which permits unrestricted use, distribution, and reproduction in any medium, provided the original author and source are credited.

Abstract
Soil contamination with various toxic metals has become a serious global concerned issue due to the potential
risks to the environmental ecology and human health. So far, numerous in-situ and ex-situ methods have been
developed and electro-kinetic (EK) enhanced phytoremediation is widely accepted as a sustainable alternative for
the decontamination. The integrated technique contains the application of a low intensity electric field adjoined to
growing plants in contaminated soil. So far, many efforts have been made while there is a clear lack of this
technology in both laboratorial and field applications. Limitations such as low phytoavailaibility of target metals,
unsatisfactory metal's tolerance and translocation ability of plants and undesirable soil pH environment might the
main reasons that responsible for the low remediation efficiency. In order to figure out the current focusing
phenomena, the possible mechanisms of phytoextraction, EKR and EKR-enhanced phytoextraction were discussed,
respectively. In addition, influencing factors such as metal speciation, plant selection and electro-kinetic parameters
were also discussed. The contents summarized in the present paper are believed to be an useful guideline for
further investigation and optimization of EK-enhanced phytoextraction.

Keywords: Metal-polluted soils; Phytoextraction; Electro-kinetic remediation; Phytoavailability; Electro-kinetic parameters

\section{Introduction}

Due to the potential risks to the environmental ecology and human health, heavy metal contamination of soils has become a serious global concerned issue [1]. Generally, the background values of heavy metals such as $\mathrm{Cr}, \mathrm{Mn}, \mathrm{Co}, \mathrm{Ni}, \mathrm{Cu}, \mathrm{Zn}, \mathrm{Cd}, \mathrm{Sn}$ and $\mathrm{Pb}$ are low in soils [2-4]. However, as rapid industrialization and urbanization, their contents in pedosphere, biosphere and hydrosphere have been largely increased in recent years. According to the reports, many countries such as Japan, Indonesia and China are suffering from the heavy metal pollution, which are mainly originated from anthropogenic activities like industrial activities, agricultural productions and mining. Among the above-mentioned pollution sources, agricultural production is believed to be an important contributor since various species of metals have been detected in agro-chemicals such as fertilizers, manures and pesticides, etc. [5]. For instance, superphosphate fertilizers, sludge and lime were found to possess certain concentration of $\mathrm{Cd}, \mathrm{As}, \mathrm{Ni}$ and $\mathrm{Cr}$ [6]. In addition, fungicides and insecticides were also reported to contain certain levels of $\mathrm{Pb}, \mathrm{Cd}, \mathrm{As}$ and $\mathrm{Zn}[7,8]$. As a result, phenomena of higher metal accumulation in soils and plants are usually obtained due to the long-term simultaneous and excessive applications of such agrochemicals in arable lands [9,10]. Several researchers have indicated that massive utilization of phosphate fertilizer could result in the content elevation of toxic $\mathrm{Cd}, \mathrm{As}, \mathrm{Cr}$ and $\mathrm{Pb}$ in cultivated soils [11]. Moreover, the widespread usage of nitrogen fertilizers which are enriched of $\mathrm{Cd}$ rise great risks to soil quality and food safety, even though the concentration of $\mathrm{Cd}$ in fertilizers is within the safety threshold [12]. Furthermore, the frequent irrigation with sewage also plays as a vital approach for metals of $\mathrm{Pb}, \mathrm{Cd}, \mathrm{As}$ and $\mathrm{Zn}$ to enter the soil environment [13-15].

In order to remediate the metal-contaminated sites, numerous insitu and $e^{X}$-situ methods involving soil replacement, thermal desorption, chemical leaching and fixation, vitrification and biological immobilization have been proposed and implemented based on the efforts spent in the last two decades [16]. However, there is a clear limitation on their widespread applications in field-scale due to the low remediation efficiencies and undesirable site conditions. Therefore, the development of innovative technology with characteristics of costeffectiveness and environmental-friendliness becomes an urgent issue.

Phytoextraction is widely accepted as a sustainable alternative for decontaminating the toxic heavy metals in soils by using different plants that capable for metal accumulation [17-35]. It was first proposed by Chaney et al. in 1983 and suitable for removing metals, radionuclides, inorganic salts and organic matters from matrix via mechanism of phytoextraction [35]. Even through phytoextraction is a novel, solar-driven efficient and easy applicable strategy, some existing restrictions still hinder its practical utilizations [36,37]. On one hand, it is difficult to find hyperaccumulators that hold favorable accumulation abilities of multiple heavy metals. On the other hand, to ensure the phytoavailability of metals in porous matrix is not easy [38].

For those reasons, various enhancements have been presented to associate phytoextraction and EKR was proved to have preferable improving performance. In brief, the EKR involves introducing a direct low-intensity electric field to mobilize target pollutants through the porous medium. The main transport mechanisms for EKR process to mobilize the metal ions include electromigration, electroosmosis and electrophoresis. As the driving force, the electric potential is beneficial for the transportation of ions toward plant's rhizosphere, which might significantly improve the phtoextraction efficiency. Meanwhile, the 
acidification effect induced by water electrolysis favors the desorption of metals from soil particles, thus largely increases metal's phytoavailability.

The integrated technique of phytoextraction and EKR is promising and worth studying in future due to its huge potential on metal decontamination. In order for better understanding of this technology, the paper described the mechanisms of phytoextraction, EKR and EKR-enhanced phytoextraction, respectively. Then, possible influencing factors which include metal speciation, plant selection and electro-kinetic parameters were also summarized and discussed for further optimization of this technique.

\section{Mechanisms of EK-enhanced phytoextraction}

\section{Phytoextraction}

Phytoremediation refers to the utilization of plants for removing, stabilizing or degrading the pollutants in environment. That is to say, the various contaminants could be degraded by plants' metabolisms, accumulated in plants' underground and aerial tissues or transformed to other species via rhizofiltration, phytoextraction, phytostabilization, phytotransformation, phytostimulation and phytovolatilization [27,39-42].

Among the above-mentioned mechanisms, phytostabilization and phytoextraction are the most popular approaches for the removal of heavy metals from soils, which aim at controlling the ecological risks and recovering market valuable elements $(\mathrm{Ni}, \mathrm{Tl}, \mathrm{Au})$ in the meantime. In terms of phytostabilization, it can significantly immobilize heavy metals through effects of root sorption, complexation, precipitation and metal (valence) reduction, thus preventing metal migration to groundwater and food chain [44-46]. As reported, with plantation of proper plants, the hazardous metals could be converted to less toxic fractions due to the function of certain redox enzymes, which largely reduced their mobility and bioavailablity in the environment [43]. In addition, the phytostabilization can also alleviate the accumulation of heavy metals in biota that further decline metals' relevant risks and damages [47]. Regarding to phytoextraction, it is divided into induced phytoextraction and continuous phytoextraction, which can remove metals from the contaminated land by extracting them to the harvestable parts of plant [48]. Generally, induced phytoextraction refers to using plants with remarkable biomass while continuous phytoextraction refers to applying hyperaccumulators with preferable extraction ability [49].

The purpose of phytoremediation is transferring or concentrating heavy metals in roots and above-ground parts of plant at high levels. However, despite the benefits and capacities, there is a obvious shortage of its applications in both laboratory and field scale. Effects such as the speciation of target metals as well as the growth of plants might be the main limitations for the widespread usage of this technique. On one hand, the lower bioavailability of investigated elements would restrict their migration to plants' rhizosphere, thus further hinder the clean-up process [50]. On the other hand, the undesirable plants' growing conditions (e.g., climates, geology, altitude and temperatures) and slower plants' growing and biomass production rate would also limit the performance of phytoremediation [51-55].

\section{Electro-kinetic remediation}

Among the various technologies, the EKR is widely accepted as the feasible alternative in-situ technique for the enhancement of phytoremediation on soil metals decontamination. Under the constant voltage gradient, metals in porous medium are mobilized towards the opposite electrode direction through mechanisms of electromigration, electroosmosis and electrophoresis (Figure 1) [56].

As so far, many studies have proved that electromigration is the dominant mechanism for cation's transport and their behaviors in soil matrix are significantly influenced by the coupling effects of chemical and geochemical reactions induced by electric field [57-60]. For instance, $\mathrm{H}^{+}$and $\mathrm{OH}^{-}$generated via water electrolysis result in the acidification and alkalization in the anode and cathode regions, respectively. Soil acidic environment is preferable for desorption of toxic metals while alkalic environment can cause species precipitation [61]. As a result, the mobilization of soluble ions are restricted by the effects of adsorption on soil particles and clogging of soil pores in alkaline condition [62].

It seems that the approving performance of EKR on metal recovery can hardly achieved without control on soil $\mathrm{pH}$. For that reason, many researchers have focused on the soil amendments (e.g., chelate, organic acid, etc.) and discovered their great superiority on soil $\mathrm{pH}$ management [63-66]. However, significant drawbacks in the damage of soil fertility and secondary pollution were also obviously observed [67-70]. Moreover, due to the relative high expense, promotion of such reagents in large-scale practice was usually difficult to implement.

Recently, great concerns have been paid to the EKR operating parameters (e.g., electrode, materials, electrical field intensity, mode of voltage application and electrodes configurations) in order to improve the efficiency of EKR-enhanced phytoremediation without additional hazard and exorbitant cost. It was reported that, with optimization of aforementioned parameters, the required time for the remediation could be highly diminished and secondary pollution during the process could be largely avoided. Thus, more detailed studies on appropriate EKR designation for different scale requirements becomes an urgent priority.

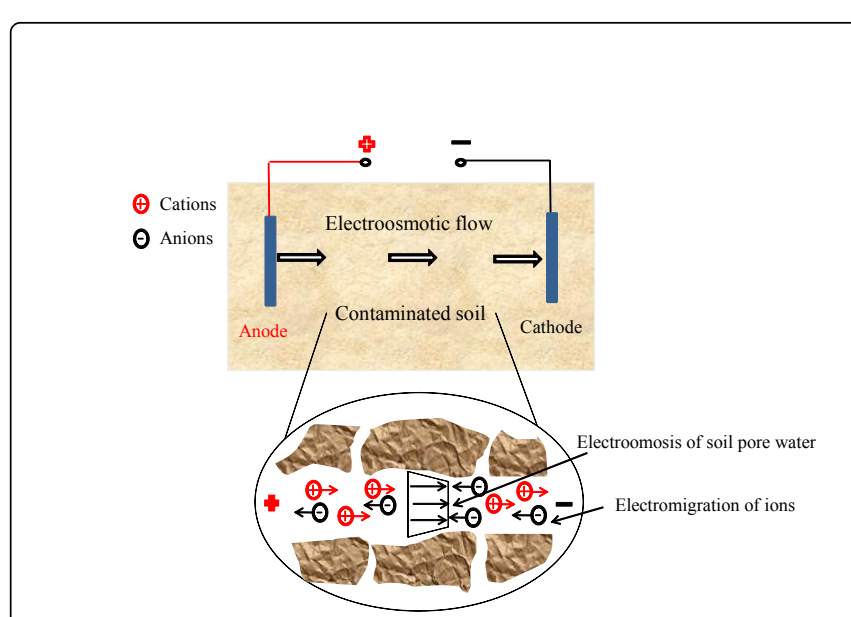

Figure 1: Main mechanisms during an electro-kinetic remediation.

\section{EK-enhanced phytoextraction}

In order to avoid the unnecessary remediation time and efforts spent on the soil metal decontamination, the combination of EKR with 
phytoremediation was proposed and tested in different scales [71]. Generally, the integrated technique contains the application of a low intensity electric field adjoined to growing plants in contaminated soil (Figure 2).

Recent researches showed that, the success of EK-enhanced phytoextraction is highly dependent on the bioavailability of metals in soil, meanwhile, the tolerance and translocation ability of plants to target metals [72-74]. Before metal(loid)s enter into plant systems from soil solution, they must be transported to root surface. However, most metals are mainly presented in solid phases such as carbonatebounded, organic-bounded and iron/manganese oxide-bounded fractions, which can hardly move [75]. Therefore, how to break metals' equilibrium and transfer them into the aqueous fractions becomes a key issue. In addition, selection of plants that hold high translocation factor (TF) of target elements also play an important role in improving metals' extraction efficiency [76].

In conclusion, understanding bioaccumulation and transport of metals by plants under EKR is essential to further recovery of pollutedsites. That is to say, the detailed mechanisms of metal decontamination with EK-enhanced phytoextraction, especially the influencing factors that responsible for the remediation performance, should be better clarified and comprehended.

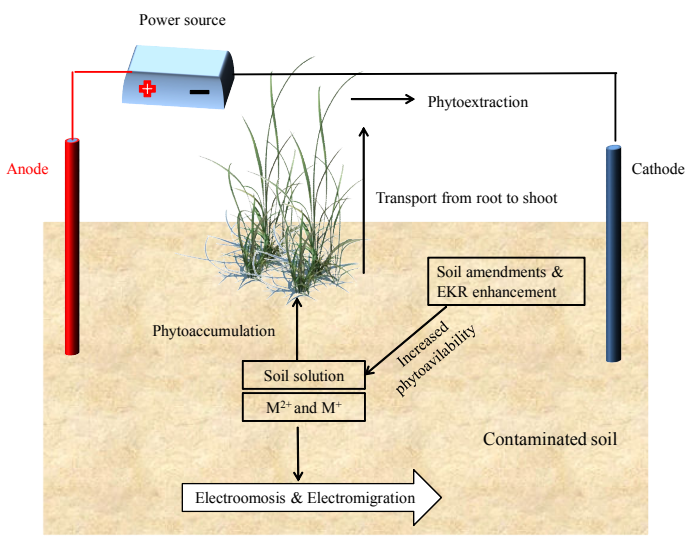

Figure 2: Schematic diagram of electro-kinetic enhanced phytoremediation.

\section{Influencing factors of electro-kinetic enhanced phytoremediation}

Metal's speciation and phytoavailability: It is well known that metals are distributed in various chemical forms in soils. Nevertheless, it is also suggested that only water and acid soluble fractions of metals are available for electromigration or plants' uptake. These fractions reflect the phytoavailability of trace metals, which is critical for evaluating the efficiency of EK-enhanced phytoextraction.

Basically, it is hard to estimate metals' speciation due to their complicated chemical activities in both environmental and biological systems [77]. As reported, metal's distribution in soil matrix is determined not only by their concentration but also environmental factors such as water availability and soil properties [78]. Hence, sequential extraction procedures are applied to selectively extract metals with a series of reagents, which aim at characterizing the partitioning of trace metals [79]. A seven-step sequential extraction method was first introduced to analyze metal's speciation by Tessier et al. in 1979 [80]. Then, for the purpose of saving time and avoiding standard deviation, many researches simplified the above analyzing method to a four-step procedure via applying extraction reagents with higher selectivity [81]. Currently, a modified three-step sequential extraction procedure proposed by Community Bureau Reference (BCR) is most popular and widely used associated with diffusive gradients thin-films technology [82].

Based on speciation analysis, soil metals are generally divided into four fractions that named exchangeable, iron/manganese oxide, organic-bounded and residual fraction, respectively [83]. According to phytoavailability, they are further divided into three categories that include readily bioavailable $(\mathrm{Cd}, \mathrm{Ni}, \mathrm{Zn}, \mathrm{As}, \mathrm{Se}, \mathrm{Cu})$, moderately bioavailable ( $\mathrm{Co}, \mathrm{Mn}, \mathrm{Fe})$ and least bioavailable $(\mathrm{Pb}, \mathrm{Cr}, \mathrm{U})$. As mentioned before, increasing the phytoavailability of soil metals is critical for improving the efficiency of EK-enhanced phytoextraction. For that reason, enhancement that derived from plant itself and external strategies have been investigated and proposed [84]. For instance, the secretion of $\mathrm{H}^{+}$ions by roots will compete the binding sites on soil particles, which lead to the release of metal cations via ion exchange. Moreover, activities of rhizospheric microbes will increase the generation of aqueous complexes, which are also beneficial for metal dissolution through the chelating effect [85]. Referring to external strategy, the purpose of EKR is to manage the $\mathrm{pH}$ of treated matrix in an acidic range, which enable to keep more metals in labile fractions. In addition, the application of chelating agents such as EDTA, ammonium sulfate, critic acid and elemental sulfur et al. are usually associated with the remediation process for further reinforcement [86]. As a result, more metals are demobilized around rhizosphere and ready for phytoextraction with the integrated enhancements above.

Plant selection: Generally, plant that ideal for EK-enhanced phytoextraction should satisfy the requirements such as high growth rate, easy to cultivate and harvest, high resistance to pathogens and pests, more above-ground biomass, highly developed root system, tolerance to targeted metals at high content, remarkable metals accumulation and translocation ability, and good adaptability to environmental and climatic changes [87-89]. It was reported that most plants metal decontamination have shallow roots, small aerial biomass and are specific to one element. Hence, great interest have been raised to explore the hyperaccumulators which possess characterizations of fast growing as well as desirable metal accumulation capacity. Hyperaccumulators are plants that hypertolerant to a certain range of metals accumulated in shoots. That is to say, the concentration of metals in their above-ground tissues is usually 100-1000 fold larger than those presented in the soil or in nearby non-accumulators [90]. Currently, there is no scientific standard to define hyperaccumulaor. Thus, hyperaccumulator selection for EK-enhanced phytoextraction can still be in challenge.

The concept of "hyperaccumulator" was first proposed by Brooks et al. and further described by Reeves as plants which capable to accumulate more than $1000 \mathrm{mg} \mathrm{kg}^{-1} \mathrm{Ni}$ in their above-ground tissues under natural habitat conditions $[90,91]$. Here, the term "aboveground tissue" should be regarded as plant foliage only and "under natural habitat conditions" indicates that hyperaccumulators must achieve metal hyperaccumulation in a healthy status. Nowadays, 
except for $\mathrm{Ni}$, more criteria are developed to define hyperaccumulaor for various metals. The basic principle for the evaluation is that metal accumulated in the shoot of hyperaccumulaors should be 100 to 1000 fold higher than that of crops or non-accumulators [92]. The recommended concentration thresholds for different metals in dried foliage matter are shown as follows: $100 \mathrm{mg} \mathrm{kg}^{-1}$ for Cd, Se and Tl; 300 $\mathrm{mg} \mathrm{kg}{ }^{-1}$ for $\mathrm{Cu}, \mathrm{Cr}$ and $\mathrm{Co} ; 1000 \mathrm{mg} \mathrm{kg}^{-1}$ for $\mathrm{Pb}, \mathrm{As}, \mathrm{Ni} ; 3000 \mathrm{mg} \mathrm{kg}^{-1}$ for $\mathrm{Zn}$; and $10000 \mathrm{mg} \mathrm{kg}^{-1}$ for Mn [93]. So far, more than 400 species have been identified as metal hyperaccumulators and many of them belong to family Brassicaceae, shown in Table 1.

\begin{tabular}{|c|c|c|c|}
\hline Binomial name & $\begin{array}{l}\text { Metal } \\
\text { species }\end{array}$ & $\begin{array}{l}\text { Metal accumulation ( } \mathrm{mg} \\
\mathbf{k g}^{-1} \text { ) }\end{array}$ & Reference \\
\hline $\begin{array}{l}\text { Alyssum } \\
\text { markgrafii }\end{array}$ & $\mathrm{Ni}$ & 19100 & [94] \\
\hline Alyssum corsicum & $\mathrm{Ni}$ & 18100 & \multirow{2}{*}{ - $[95]$} \\
\hline Alyssum caricum & $\mathrm{Ni}$ & 12500 & \\
\hline $\begin{array}{l}\text { Euphorbia } \\
\text { cheiradenia }\end{array}$ & $\mathrm{Pb}$ & 1138 & [96] \\
\hline $\begin{array}{l}\text { Eleocharis } \\
\text { acicularis }\end{array}$ & As & 1470 & [97] \\
\hline \multirow{2}{*}{ Petris vittata } & As & 8331 & \multirow{2}{*}{ [98] } \\
\hline & $\mathrm{Cr}$ & 20675 & \\
\hline Azolla pinnata & $\mathrm{Cd}$ & 740 & [99] \\
\hline $\begin{array}{l}\text { Thlaspi } \\
\text { caerulescens }\end{array}$ & $\mathrm{Cd}$ & 263 & [100] \\
\hline \multirow{2}{*}{$\begin{array}{l}\text { Eleocharis } \\
\text { acicularis }\end{array}$} & $\mathrm{Zn}$ & 11200 & \multirow{2}{*}{ [101] } \\
\hline & $\mathrm{Cu}$ & 20200 & \\
\hline $\begin{array}{l}\text { Amaranthus } \\
\text { chlorostachys }\end{array}$ & Cs & 2146 & \multirow{2}{*}{ [102] } \\
\hline $\begin{array}{l}\text { Pennisetum } \\
\text { purpureum Schum }\end{array}$ & Cs & 26365 & \\
\hline
\end{tabular}

Table 1: List of some hyperaccumulators.

Another principle for hyperaccumulator exploration is plant's translocation factor (TF) and bioconcentration factor (BCF). The TF and $\mathrm{BCF}$ of plant represent the ratio of metal content from shoots to roots and harvested tissues to soils, respectively [103]. It is indicated that plants with both TF and BCF lager than 1 have the preferable potential for phytoextraction. It should be noted that, as the important indicator, the value of TF and BCF can be as high as 50-100, while can also be less than 1 if the metal's concentration in soil was extremely high [104].

\section{Electro-kinetic parameters}

Electrode material: Electrode material selection is primarily based on the reactive equilibriums occurred on their surface as well as their inherent thermal, mechanical and corrosive resistance [105]. Many studies have revealed that, the oxide film formed on the electrode surface could significantly block electrode active sites and increase the electric resistance during the EKR process [106]. Thus, electrode precoating with material such as platinum, silver, gold and titanium is required in order to increase the roughness and surface active sites of the electrode.

Recently, there is a growing interest in using graphite as electrode material due to their low cost and good accessibility. Since phenomena like oxide film formation and surface precipitation still restrain it lifetime and reactive activity, modifications are always required [107]. Many researchers suggested that forming a thin layer by using metallic oxide on electrode surface (i.e., $\mathrm{Ti} / \mathrm{SnO}_{2}-\mathrm{Sb}_{2} \mathrm{O}_{3}$, carbon/TiO $2, \mathrm{Ti} / \mathrm{IrO}_{2}$ ) could be a effective approach as modification [108]. In that way, the modified electrode can be used as both anode and cathode, which is given the name of "Dimensionally Stable Anode" due to its improved resistance to reactive species and $\mathrm{pH}$ changes [109].

Electrical field intensity: Electric field intensity is a determining factor in influencing the effectiveness of EK-enhanced phytoextraction. Lemström [60] did the first large-scale experiment to investigate the influence of voltage gradient on plants growth in early 20 th century. In that study, a constant electric field of $10 \mathrm{kV} \mathrm{m}^{-1}$ was applied and greener morphological characteristics and dramatic increases in yield were observed from the treated plants. The later studies obtained the similar consequences that electrical field had positive effect on plant's germination and growth rate, while the relative mechanisms were not well explained so far [61]. Except for the benefit, some other scholars also pointed out that damage can be shown on plant's leaves with higher electric field, which indicated that plant's growth is not simply proportional to voltage gradient. Optimization of electrical field intensity for different plant species and the possible damage theories need a further investigation.

It seems that the possible damage theories and optimal electric field intensity for different plant species need further investigation. Cang et al. [62] recently studied the influence of voltage on phytoextraction by using Indian mustard. They found that low electric field was beneficial for Indian mustard's growth since its biomass production was decreased as the increase of voltage. In addition, as the bioavailability of heavy metals was elevated with increasing voltage, the tradeoff for balancing it with voltage negative effects on plant's growth was considered and voltage lower than $2 \mathrm{~V} / \mathrm{cm}$ was suggested to be preferable in that case [110]. Similar results were also obtained in other studies that under voltage between $0.5-2 \mathrm{~V} / \mathrm{cm}$, both plant biomass production and metal accumulation could achieve satisfying performance.

Mode of applied voltage: Previous studies showed increasing bioavailability of soil metals while unfavorable $\mathrm{pH}$ polarization under direct current field (DC). The $\mathrm{pH}$ polarization, especially alkalization directly restricts the growth of plant as well as the migration of metals [63]. Therefore, alternative current field (AC) which involves a period exchange in polarity direction is studied in order to maintain soil $\mathrm{pH}$ in an acceptable range. Aboughalma et al. remediated metal-polluted soils by using potato integrated with electric current AC and DC, respectively [67]. They found that the initial $\mathrm{pH}$ value (6.5) was decreased to 3 near the anode regions and increased to 8 near the cathode regions, respectively with application of DC. The target metals had a migration from anode toward cathode while accumulated in the area of $\mathrm{pH}$ jumping point. On the contrary, no polarization and sharp transition of soil $\mathrm{pH}$ was observed with application of AC. Furthermore, potato had a $72 \%$ increase whereas a $27 \%$ decline of biomass production under $\mathrm{AC}$ and $\mathrm{DC}$, respectively. As a result, potato grew under $\mathrm{AC}$ showed higher metal accumulation in both roots and shoots than those in the control and DC test. Bi et al. investigated the phytoextraction under electric field with polarity reversal every $3 \mathrm{~h}$ 
[83]. Under this voltage mode, they discovered that the soil $\mathrm{pH}$ polarization could be totally eliminated and no significant alteration in soil physico-chemical properties was shown. Overall, plant reactions to different electric fields are more or less beneficial for plant biomass production, metal uptake and metal translocation, and the mode of $\mathrm{AC}$ shows a better impact on EK-enhanced phytoextraction.

Electrode configuration: Electrode configuration is also an important parameter in influencing the effectiveness of EK-enhanced phytoextraction. Until now, many efforts have been made on this issue: Zhou et al. used a vertical DC which extended the phytoextraction depth and prevented the leaching of $\mathrm{Pb}$ Hodlko et al. [111] proposed several electrode arrangements to prevent the leaching of mobilized metals. They suggested the electrode configuration that placed the cathode in the center with anodes surrounded had the greatest potential for metals accumulation [112], In addition, Putra et al. designed a $2 \mathrm{D}$ electrode configuration with cathode placed on the top layer of soil and anodes vertically installed in four corners of a rectangular chamber. The results showed enhancement in both metal accumulation and translocation in plants tissues [113]. Based on previous study, electrode configurations are generally divided into unidirectional, and bidirectional and radial types (Figure 3) [114]. They are applied to treat different soil matrix in order to achieve the demanded outcomes. For instance, bidirectional configuration is more effective on metals transportation at high concentration while radial type is more suitable for homogeneous remediation of multi-metals contaminated soil.

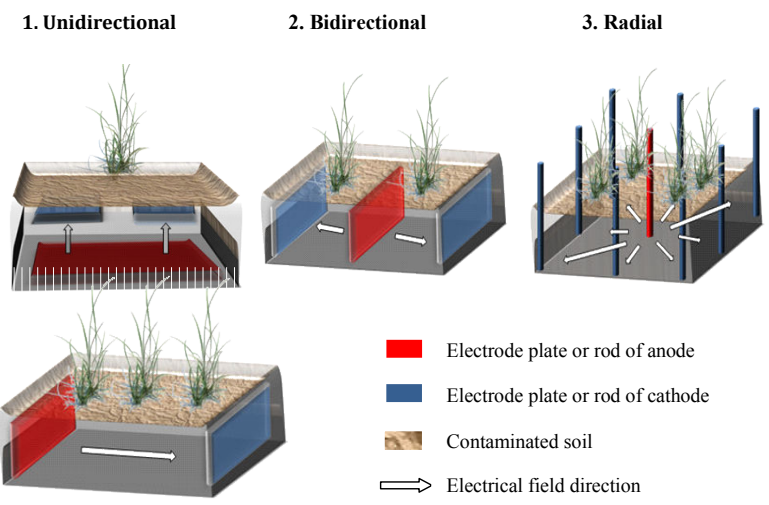

Figure 3: Illustration of 1 Unidirectional, 2 Bidirectional and 3. Radial electrode configurations.

During the electrode configuration designation, many factors such as electrode spacing and cell selection should be carefully considered [111]. Since electrode spacing was found to be inversely proportional to electric field intensity, increasing the electrode distance might cause the reduction of electrical potential and migration of elements, thus extend the remediation period [115]. In addition, selection of experimental setup without constituting electrical conductive material can prevent the short circuit during the EKR [116].

\section{Conclusions}

This article clarified and summarized the possible mechanisms and influcing factors of EK-enhanced phytoextraction for remediation of metal-polluted soils. In terms of mechanisms, phytoextraction is a sustainable process for reducing the concentration of metals in soils via various plants. It is a novel, solar-driven efficient, in situ applicable, cost-effective and eco-friendly remediation approach which highly dependent on metal's phytoavailability for its success. EKR involves introducing a direct low-intensity electric field to mobilize target pollutants through the porous medium. The main transport mechanisms for EKR process to mobilize the metal ions include electromigration, electroosmosis and electrophoresis. It is a promising enhancement for increasing metal's phytoavilability as well as plant growth. However, soil $\mathrm{pH}$ polarization induced by electrolysis of water during the process still restrict its performance. Thus, strategies like polarity reversal in certain frequency and addition of soil amendments are usually associated with the EK-enhanced phytoextraction in order to keep the soil $\mathrm{pH}$ in an acidic range. Regarding to influencing factors, metal's speciation analysis through sequential extraction method is important since only water and acid soluble fractions of metals are available for electromigration or plants' uptake. Based on this procedure, relevant suggestions can be determined for transforming the stable metals to labile fractions. Selection of proper hyperaccumlator which possesses characteristics of high growth rate, high resistance to target metals, remarkable metals accumulation and translocation ability, and good adaptability to environmental and climatic changes is also critical for EK-enhanced phytoextraction. The basic principle for plant's selection include metal's accumulation in the aboveground tissues as well as the TF and BCF of the plant. Moreover, electrical parameters that include electrode material, electrical field intensity, mode of applied voltage and electrode configuration is another important issue. There parameters can highly determine the efficiency of EK-enhanced phytoextraction by influencing the transport-reactive equilibriums and geo-chemical reactions of trace metals in soil matrix. In summary, the mechanisms and influencing factors in the present study are important in the context of the existing literature and for the application and optimization of EK-enhanced phytoextraction as an in-situ decontamination. We believe that the contents discussed in this paper can applied as an useful guideline for further investigation of EK-enhanced phytoextraction.

\section{Acknowledgements}

This work was supported financially by "the Fundamental Research Funds for the Central Universities" (2017B11014, 2017B20414, 2018B42614), "the China Postdoctoral Science Foundation" (2017M611677) and "Jiangsu Scientific Research Program"(BE2015705, BE2017765). The authors would like to thank all the beneficiaries of the project for the support and assistance provided.

\section{References}

1. Han FX, Banin A, Su Y, Monts DL, Plodinec JM, et al. (2002) Industrial age anthropogenic inputs of heavy metals into the pedosphere. Naturwissenschaften 89: 497-504.

2. Han FX, Su Y, Monts DL, Plodinec MJ, Banin A, et al. (2003) Assessment of global industrial-age anthropogenic arsenic contamination. Naturwissenschaften 90: 395-401.

3. Cameselle C, Chirakkara RA, Reddy KR (2013) Electrokinetic-enhanced phytoremediation of soils: status and opportunities. Chemosphere 93: 626-636.

4. Callender E (2003) Heavy metals in the environment-historical trends. Treatise on Geochemistry 9: 612. 
5. Alloway BJ, Jackson AP, Morgan H (1990) The accumulation of cadmium by vegetables grown on soils contaminated from a variety of sources. Science of the Total Environment 91: 223-236.

6. Taylor MD, Percival HJ (2001) Cadmium in soil solutions from a transect of soils away from a fertiliser bin. Environmental Pollution 113: 35-40.

7. Mansour SA, Belal MH, Abou-Arab AA, Gad MF (2009) Monitoring of pesticides and heavy metals in cucumber fruits produced from different farming systems. Chemosphere 75: 601-619.

8. Pastor J, Hernández AJ (2012) Heavy metals, salts and organic residues in old solid urban waste landfills and surface waters in their discharge areas: determinants for restoring their impact. Journal of Environmental Management 95: S42-S49.

9. Wang H, Dong Y, Yang Y, Toor GS, Zhang X (2013) Changes in heavy metal contents in animal feeds and manures in an intensive animal production region of China. Journal of Environmental Sciences 25: 2435-2442.

10. Zakir S, Shang Z, Yanli XU, Lili ZH, Chunjie LI (2011) Assessment of heavy metals in grain fields with long-term treatment of agrochemicals and organic manure in Hailun City of Northeast China. Journal of Northeast Agricultural University 18: 30-35.

11. Ross SM (1994) Retention, transformation and mobility of toxic metals in soils. In: Ross SM (Ed.), Toxic metals in soil-plant systems. John Wiley \& Sons Inc., London.

12. Wångstrand H, Eriksson J, Öborn I (2007) Cadmium concentration in winter wheat as affected by nitrogen fertilization. European Journal of Agronomy 26: 209-214.

13. Chang YS, Chang YJ, Lin CT, Lee MC, Wu CW (2013) Nitrogen fertilization promotes the phytoremediation of cadmium in Pentas lanceolata. International Biodeterioration \& Biodegradation 85: 709-714.

14. Gleyzes C, Tellier S, Astruc M (2002) Fractionation studies of trace elements in contaminated soils and sediments: a review of sequential extraction procedures. TrAC Trends in Analytical Chemistry 21: 451-467.

15. Sundaray SK, Nayak BB, Lin S, Bhatta D (2011) Geochemical speciation and risk assessment of heavy metals in the river estuarine sediments-a case study: Mahanadi basin, India. Journal of hazardous materials 186: 1837-1846.

16. Yao Z, Li J, Xie H, Yu C (2012) Review on Remediation Technologies of Soil Contaminated by Heavy Metals. Procedia Environmental Sciences 16: 722-729.

17. Han FX, Su Y, Sridhar BM, Monts DL (2004) Distribution, transformation and bioavailability of trivalent and hexavalent chromium in contaminated soil. Plant and Soil 265: 243-252.

18. Han FX, Sridhar BM, Monts DL, Su Y (2004) Phytoavailability and toxicity of trivalent and hexavalent chromium to Brassica juncea. New Phytologist 162: 489-499.

19. Han FX, Kingery WL, Selim HM, Gerard PD, Cox MS (2004) Accumulation and solubility of arsenic in poultry wastes and wasteamended soils. The Science of the Total Environment 320: 51-61.

20. Han FX, Su Y, Monts DL, Waggoner CA, Plodinec MJ (2006) Binding, distribution, and plant uptake of mercury in a soil from Oak Ridge, Tennessee, USA. Science of Total Environment 368: 753-768.

21. Han FX, Patterson WD, Xia Y, Sridhar BM, Su Y (2006) Rapid determination of mercury in plant and soil samples using inductively coupled plasma atomic emission spectroscopy, a comparative study. Water, Air and Soil Pollution 170: 161-171.

22. Han FX, Su Y, Monts DL (2013) Mercury Speciation and Bioavailability in Floodplain Soils of East Fork Poplar Creek, Oak Ridge, Tennessee, USA. In Floodplains: Environmental Management, Restoration and Ecological Implications. In: Cabezas A (ed.), Nova Science Publishers, Inc. NY, USA.

23. Sridhar BM, Diehl SV, Han FX, Monts DL, Su Y (2005) Anatomical changes due to uptake and accumulation of zinc and cadmium in Indian mustard (Brassica juncea). Environmental and Experimental Botany 54: 131-141.
24. Sridhar MB, Han FX, Diehl SV, Monts DL, Su Y (2007) Monitoring the effects of arsenic and chromium accumulation in Chinese brake fern (pteris vittata). International Journal of Remote Sensing 28: 1055-1067.

25. Sridhar BM, Han FX, Diehl SV, Monts DL, Su Y (2007) Spectral reflectance and leaf internal structure changes of barley plants due to phytoextraction of zinc and cadmium. International Journal of Remote Sensing 28: 1041-1054

26. Su Y, Sridhar BM, Han FX, Diehl SV, Monts DL (2007) Effects of bioaccumulation of Cs and Sr natural isotopes on foliar structure and plant spectral reflectance of Indian mustard (Brassica Juncea). Water, Air and Soil Pollution 180: 65-74.

27. Su Y, Han FX, Chen J, Sridhar BM, Monts DL (2008) Phytoextraction and accumulation of mercury in three plant species: Indian mustard (Brassica juncea), Beard grass (Polypogon monospeliensis), and Chinese brake fern (Pteris vittata). International Journal of Phytoremediation 10: 547-560.

28. Chen J, Shiyab S, Han FX, Monts DL, Waggoner CA, et al. (2009) Bioaccumulation and physiological effects of mercury in Pteris vittata and Nephrolepis exaltata. Ecotoxicology 18: 110-121.

29. Jian C, Yang Z, Su Y, Han FX, Monts DL (2009) Phytoremediation of heavy metal/metalloid-contaminated soils. In: Steinberg RV (ed.), Contaminated Soils: Environmental Impact, Disposal and Treatment. Nova Science Publishers, New York, USA.

30. Chen J, Shi Z, Bin Hu L, Su Y, Han F (2010) Site Assessment, Long-term Monitoring and Regulatory Concerns for Application of Phytoremediation Technology for Remediation of Heavy Metal/Metalloid -Contaminated Soils. In: Faerber T, Herzog J (eds.), Solid Waste Management and Environmental Remediation. Nova Science Publishers, New York, USA.

31. Chen J, Chen Y, Shi ZQ, Su Y, Han FX (2013) Phytoremediation to remove metals/metalloids from soils. In Phytoremediation: Management of Environmental Contaminants, pp: 297-304.

32. Shiyab S, Chen J, Han FX, Monts DL, Matta FB (2009) Phytotoxicity of mercury in Indian mustard (Brassica juncea L). Ecotoxicology and Environmental Safety 72: 619-625.

33. Shiyab S, Chen J, Han FX, Monts DL, Matta FB, et al. (2009) Mercuryinduced oxidative stress in Indian mustard (Brassica juncea L.) Environmental Toxicology 24: 462-471.

34. Chaney RL, Malik M, Li YM, Brown SL, Brewer EP (1997) Phytoremediation of soil metals. Current Opinion in Biotechnology 8: 279-284.

35. Greipsson S (2012) Catastrophic soil erosion in Iceland: Impact of longterm climate change, compounded natural disturbances and human driven land-use changes. Catena 98: 41-54.

36. McCutcheon SC, Jørgensen SE (2008) Phytoremediation. In Reference Module in Earth Systems and Environmental Sciences. Encyclopedia of Ecology. Elsevier Inc. Amsterdam, Netherlands.

37. Bhardwaj R, Sharma R, Handa N, Kaur H, Kaur R, et al. (2014) Prospects of Field Crops for Phytoremediation of Contaminants. Emerging Technologies and Management of Crop Stress Tolerance 2: 449-470.

38. O'connor CS, Lepp NW, Edwards R, Sunderland G (2003) The Combined Use of Electrokinetic Remediation and Phytoremediation to Decontaminate Metal-Polluted Soils: A Laboratory-Scale Feasibility Study. Environmental Monitoring and Assessment 84: 141-158.

39. Yeung AT, Gu YY (2011) A review on techniques to enhance electrochemical remediation of contaminated soils. Journal of Hazardous Materials 195: 11-29.

40. Bi R, Schlaak M, Siefert E, Lord R, Connolly H (2011) Influence of electrical fields (AC and DC) on phytoremediation of metal polluted soils with rapeseed (Brassica napus) and tobacco (Nicotiana tabacum). Chemosphere 83: 318-326.

41. Dhankher OP, Pilon-Smits EA, Meagher RB, Doty S (2012) Biotechnological approaches for phytoremediation. In: Altman A, Hasegawa PM (eds.), Plant Biotechnology and Agriculture, pp: 309-328.

42. Pirzadah TB, Malik B, Tahir I, Kumar M, Varma A, et al. (2014) Phytoremediation: An Eco-Friendly Green Technology for Pollution 
Prevention, Control and Remediation. Soil Remediation and Plants 5: 107-126.

43. Bolan NS, Park JH, Robinson B, Naidu R, Huh KY (2011) Phytostabilization: A Green Approach to Contaminant Containment. Advances in Agronomy 112: 145-204.

44. Ferraz P, Fidalgo F, Almeida A, Teixeira J (2012) Phytostabilization of nickel by the zinc and cadmium hyperaccumulator Solanum nigrum L. Are metallothioneins involved?. Plant Physiology and Biochemistry 57: 254-260.

45. Lee SH, Ji W, Lee WS, Koo N, Koh IH, et al. (2014) Influence of amendments and aided phytostabilization on metal availability and mobility in $\mathrm{Pb} / \mathrm{Zn}$ mine tailings. Journal of Environmental Management 139: 15-21.

46. Testiati E, Parinet J, Massiani C, Laffont-Schwob I, Rabier J, et al. (2013) Trace metal and metalloid contamination levels in soils and in two native plant species of a former industrial site: Evaluation of the phytostabilization potential. Journal of Hazardous Materials 249: 131-141.

47. Kumpiene J, Guerri G, Landi L, Pietramellara G, Nannipieri P, et al. (2009) Microbial biomass, respiration and enzyme activities after in situ aided phytostabilization of $\mathrm{a} \mathrm{Pb}$ - and $\mathrm{Cu}$-contaminated soil. Ecotoxicology and Environmental Safety 72: 115-119.

48. Raskin I, Smith RD, Salt DE (1997) Phytoremediation of metals: using plants to remove pollutants from the environment. Current Opinion in Biotechnology 8: 221-226.

49. Kos B, Leštan D (2004) Chelator induced phytoextraction and in situ soil washing of $\mathrm{Cu}$. Environmental Pollution 132: 333-339.

50. Quartacci MF, Irtelli B, Baker AJ, Navari-Izzo F (2007) The use of NTA and EDDS for enhanced phytoextraction of metals from a multiply contaminated soil by Brassica carinata. Chemosphere 68: 1920-1928.

51. Clemens S, Palmgren MG, Krämer U (2002) A long way ahead: understanding and engineering plant metal accumulation. Trend Plant Sci 7: 309-315.

52. Rungwa S, Arpa G, Sakulas H, Harakuwe A, Timi D (2013) Phytoremediation-An Eco-friendly and Sustainable Method of Heavy Metal Removal from Closed Mine Environments in Papua New Guinea. Procedia Earth and Planetary Science 6: 269-277.

53. Prasad MN, Freitas H, Fraenzle S, Wuenschmann S, Markert B (2010) Knowledge explosion in phytotechnologies for environmental solutions. Environmental Pollution 158: 18-23.

54. Varaprasad MN (2011) Knowledge explosion in soil and water efficiency enhancing phytotechnologies for remediation-energy-health and sustainability. Current Opinion in Biotechnology 22: S31.

55. Malik B, Tanveer BP, Inayatullah T, Tanveer UH, Reiaz UI, et al. (2015) Recent Trends and Approaches in Phytoremediation. Soil Remediation and Plants. Elsevier Inc, New York, USA.

56. Cameselle C, Reddy KR (2012) Development and enhancement of electro-osmotic flow for the removal of contaminants from soils. Electrochimica Acta 86: 10-22.

57. Dermont G, Bergeron M, Mercier G, Richer-Laflèche M (2008) Soil washing for metal removal: a review of physical/chemical technologies and field applications. Journal of Hazardous Materials 152: 1-31.

58. Ottosen LM, Pedersen AJ, Hansen HK, Ribeiro AB (2007) Screening the possibility for removing cadmium and other heavy metals from wastewater sludge and bio-ashes by an electrodialytic method. Electrochimica Acta 52: 3420-3426.

59. Lima AT, Kleingeld PJ, Heister K, Loch JG (2012) In situ electro-osmotic cleanup of tar contaminated soil-Removal of polycyclic aromatic hydrocarbons. Electrochimica Acta 86: 142-147.

60. Lemström S (1904) Electricity in agriculture and horticulture. The Electrician Printing \& Publishing Company Inc., London, UK.

61. Bedmar ML, Pérez-Sanz A, Martinez-Inigo MJ, Benito AP (2009) Influence of Coupled Electrokinetic-Phytoremediation on Soil Remediation. Electrochemical Remediation Technologies for Polluted Soils, Sediments and Groundwater. John Wiley \& Sons Inc, Hoboken, New Jersey, USA, pp: 417-37.
62. Couto N, Guedes P, Zhou DM, Ribeiro AB (2015) Integrated perspectives of a greenhouse study to upgrade an antimony and arsenic mine soilPotential of enhanced phytotechnologies. Chemical Engineering Journal 262: 563-570.

63. Cang L, Wang QY, Zhou DM, Xu H (2011) Effects of electrokineticassisted phytoremediation of a multiple-metal contaminated soil on soil metal bioavailability and uptake by Indian mustard. Separation and Purification Technology 79: 246-253.

64. Bi R, Schlaak M, Siefert E, Lord R, Connolly H (2010) Alternating current electrical field effects on lettuce (Lactuca sativa) growing in hydroponic culture with and without cadmium contamination. Journal of Applied Electrochemistry 40: 1217-1223.

65. Lim JM, Salido AL, Butcher DJ (2004) Phytoremediation of lead using Indian mustard (Brassica juncea) with EDTA and electrodics. Microchemical Journal 76: 3-9.

66. Suzuki T, Niinae M, Koga T, Akita T, Ohta M, et al. (2014) EDDSenhanced electrokinetic remediation of heavy metal-contaminated clay soils under neutral $\mathrm{pH}$ conditions. Colloids and Surfaces A: Physicochemical and Engineering Aspects 440: 145-150.

67. Bolan N, Kunhikrishnan A, Thangarajan R, Kumpiene J, Park J, et al. (2014) Remediation of heavy metal(loid)s contaminated soils - To mobilize or to immobilize. Journal of Hazardous Materials 266: 141-166.

68. Leštan D, Luo CL, Li XD (2008) The use of chelating agents in the remediation of metal-contaminated soils: A review. Environmental Pollution 153: 3-13.

69. Liphadzi MS, Kirkham MB, Paulsen GM (2006) Auxin-enhanced root growth for phytoremediation of sewage-sludge amended soil. Environmental Technology 27: 695-704.

70. Ebrahimi M (2014) Effect of EDTA and DTPA on Phytoremediation of $\mathrm{Pb}-\mathrm{Zn}$ Contaminated Soils by Eucalyptus camaldulensis Dehnh and Effect on Treatment Time. Desert 19: 65-73.

71. Chigbo C, Batty L (2013) Effect of EDTA and citric acid on phytoremediation of Cr- B[a]P-co-contaminated soil. Environmental Science and Pollution Research 20: 8955-8963.

72. Shen Z, Zhang J, Qu L, Dong Z, Zheng S, et al. (2009) A modified EK method with an I-/I2 lixiviant assisted and approaching cathodes to remedy mercury contaminated field soils. Environmental Geology 57: 1399-1407.

73. Kim GN, Jung YH, Lee JJ, Moon JK, Jung CH (2008) An analysis of a flushing effect on the electrokinetic-flushing removal of cobalt and cesium from a soil around decommissioning site. Separation and Purification Technology 63: 116-121.

74. Maturi K, Reddy KR (2006) Simultaneous removal of organic compounds and heavy metals from soils by electrokinetic remediation with a modified cyclodextrin. Chemosphere 63: 1022-1031.

75. Chen JL, Yang SF, Wu CC, Ton S (2011) Effect of ammonia as a complexing agent on electrokinetic remediation of copper-contaminated soil. Separation and Purification Technology 79: 157-163.

76. Moreno FN, Anderson CW, Stewart RB, Robinson BH, Ghomshei M, et al. (2005) Induced plant uptake and transport of mercury in the presence of sulphur-containing ligands and humic acid. New Phytologist 166: 445-454.

77. Walker DJ, Clemente R, Bernal MP (2004) Contrasting effects of manure and compost on soil $\mathrm{pH}$, heavy metal availability and growth of Chenopodium album L. in a soil contaminated by pyritic mine waste. Chemosphere 57: 215-224.

78. Redman AD, Macalady DL, Ahmann D (2002) Natural Organic Matter Affects Arsenic Speciation and Sorption onto Hematite. Environmental Science \& Technology 36: 2889-2896.

79. Udovic M, McBride MB (2012) Influence of compost addition on lead and arsenic bioavailability in reclaimed orchard soil assessed using Porcellio scaber bioaccumulation test. Journal of Hazardous Materials 206: 144-149.

80. Clemente R, Hartley W, Riby P, Dickinson NM, Lepp NW (2010) Trace element mobility in a contaminated soil two years after field-amendment 
Citation: Mao X, Yang X, Qin H, Shao X, Zhang Z, et al. (2018) Mechanisms and Influencing Factors of Electro-Kinetic Enhanced Phytoextraction for the Recovery of Metal-Polluted Soils. J Environ Anal Toxicol 8: 586. doi:10.4172/2161-0525.1000586

Page 8 of 8

with a greenwaste compost mulch. Environmental Pollution 158: 1644-1651.

81. Houben D, Evrard L, Sonnet P (2013) Beneficial effects of biochar application to contaminated soils on the bioavailability of $\mathrm{Cd}, \mathrm{Pb}$ and $\mathrm{Zn}$ and the biomass production of rapeseed (Brassica napus L.). Biomass and Bioenergy 57: 196-204.

82. Wu L, Li Z, Akahane I, Liu L, Han C, et al. (2012) Effects of organic amendments on $\mathrm{Cd}, \mathrm{Zn}$ and $\mathrm{Cu}$ bioavailability in soil with repeated phytoremediation by sedum plumbizincicola. International Journal of Phytoremediation 14: 1024-1038.

83. Tu C, Zheng CR, Chen HM (2000) Effect of applying chemical fertilizers on forms of lead and cadmium in red soil. Chemosphere 41: 133-138.

84. Maier NA, McLaughlin MJ, Heap M, Butt M, Smart MK (2002) Effect of nitrogen source and calcitic lime on soil $\mathrm{pH}$ and potato yield, leaf chemical composition, and tuber cadmium concentrations. Journal of Plant Nutrition 25: 523-544.

85. Grant RM (1996) Toward a konwledge-based theory of the firm. Strategic Management Journal 17: 109-122.

86. Liu J, Qian M, Cai G, Yang J, Zhu Q (2007) Uptake and translocation of $\mathrm{Cd}$ in different rice cultivars and the relation with $\mathrm{Cd}$ accumulation in rice grain. Journal of Hazardous Materials 143: 443-447.

87. Cui Y, Dong Y, Li H, Wang Q (2004) Effect of elemental sulphur on solubility of soil heavy metals and their uptake by maize. Environment International 30: 323-328.

88. Rascio N, Navari-Izzo F (2011) Heavy metal hyperaccumulating plants: How and why do they do it? And what makes them so interesting? Plant Science 180: 169-181.

89. Memon AR, Schröder P (2009) Implications of metal accumulation mechanisms to phytoremediation. Environmental Science and Pollution Research 16: 162-175.

90. Brooks RR, Lee J, Reeves RD, Jaffré T (1977) Detection of nickeliferous rocks by analysis of herbarium specimens of indicator plants. Journal of Geochemical Exploration 7: 49-57.

91. Reeves RD, Baker AJ, Borhidi A, Berazain R (1999) Nickel Hyperaccumulation in the Serpentine Flora of Cuba. Annals of Botany 83: 29-38.

92. Van der Ent A, Baker AJ, Reeves RD, Pollard AJ, Schat H (2013) Hyperaccumulators of metal and metalloid trace elements: Facts and fiction. Plant and Soil 362: 319-334.

93. Li YM, Chaney R, Brewer E, Roseberg R, Angle JS, et al. (2003) Development of a technology for commercial phytoextraction of nickel: economic and technical considerations. Plant and Soil 249: 107-115.

94. Bani A, Pavlova D, Echevarria G, Mullaj A, Reeves RD, et al. (2010) Nickel hyperaccumulation by the species of Alyssum and Th laspi (Brassicaceae) from the ultramafi c soils of the Balkans. Botanica Serbica 34: 3-14.

95. Sakakibara M, Ohmori Y, Ha NT, Sano S, Sera K (2011) Phytoremediation of heavy metal-contaminated water and sediment by Eleocharis acicularis. Clean Soil, Air, Water 39: 735-741.

96. Kalve S, Sarangi BK, Pandey RA, Chakrabarti T (2011) Arsenic and chromium hyperaccumulation by an ecotype of Pteris vittata-prospective for phytoextraction from contaminated water and soil. Current Science 100: 888-894

97. Lombi E, Zhao FJ, Dunham SJ, McGrath SP (2001) Phytoremediation of heavy metal-contaminated soils: natural hyperaccumulation versus chemically enhanced phytoextraction. Journal of Environmental Quality 30: 1919-1926.
98. Moogouei R, Borghei M, Arjmandi R (2011) Phytoremediation of stable Cs from solutions by Calendula alata, Amaranthus chlorostachys and Chenopodium album. Ecotoxicology and Environmental Safety 74: 2036-2039.

99. Ali H, Khan E, Sajad MA (2013) Phytoremediation of heavy metalsConcepts and applications. Chemosphere 91: 869-881.

100. Cluis C (2004) Junk-greedy Greens: phytoremediation as a new option for soil decontamination. BioTeach Journal 2: 61-67.

101. Méndez E, Pérez M, Romero O, Beltrán ED, Castro S, et al. (2012) Effects of electrode material on the efficiency of hydrocarbon removal by an electrokinetic remediation process. Electrochimica Acta 86: 148-156.

102. Ribeiro AB, Rodriguez-Maroto JM, Mateus EP, Gomes H (2005) Removal of organic contaminants from soils by an electrokinetic process: the case of atrazine.: Experimental and modeling. Chemosphere 59: 1229-1239.

103. Saichek RE, Reddy KR (2003) Effect of pH control at the anode for the electrokinetic removal of phenanthrene from kaolin soil. Chemosphere 51: 273-287.

104. Wang JY, Huang XJ, Kao JC, Stabnikova O (2007) Simultaneous removal of organic contaminants and heavy metals from kaolin using an upward electrokinetic soil remediation process. Journal of Hazardous Materials 144: 292-299.

105. Hu JM, Meng HM, Zhang JQ, Cao CN (2002) Degradation mechanism of long service life $\mathrm{Ti} / \mathrm{IrO} 2-\mathrm{Ta} 2 \mathrm{O} 5$ oxide anodes in sulphuric acid. Corrosion Science 44: 1655-1668.

106. Comninellis C (1994) Electrocatalysis in the electrochemical conversion/ combustion of organic pollutants for waste water treatment. Electrochimica Acta 39: 1857-1862.

107. Muraji M, Asai T, Tatebe W (1998) Primary root growth rate of Zea mays seedlings grown in an alternating magnetic field of different frequencies. Bioelectrochemistry and Bioenergetics 44: 271-273.

108. Murr LE (1966) Physiological stimulation of plants using delayed and regulated electric field environments. International Journal of Biometeorology 10: 147-153.

109. Cang L, Zhou DM, Wang QY, Fan GP (2012) Impact of electrokineticassisted phytoremediation of heavy metal contaminated soil on its physicochemical properties, enzymatic and microbial activities. Electrochimica Acta 86: 41-48.

110. Luo C, Shen Z, Li X (2005) Enhanced phytoextraction of Cu, Pb, Zn and Cd with EDTA and EDDS. Chemosphere 59: 1-11.

111. Zhou DM, Chen HF, Cang L, Wang YJ (2007) Ryegrass uptake of soil $\mathrm{Cu} / \mathrm{Zn}$ induced by EDTA/EDDS together with a vertical direct-current electrical field. Chemosphere 67: 1671-1676.

112. Putra RS, Ohkawa Y, Tanaka S (2013) Application of EAPR system on the removal of lead from sandy soil and uptake by Kentucky bluegrass (Poa pratensis L.). Separation and Purification Technology 102: 34-42.

113. Gill RT, Harbottle MJ, Smith JW, Thornton SF (2014) Electrokineticenhanced bioremediation of organic contaminants: A review of processes and environmental applications. Chemosphere 107: 31-42.

114. Luo Q, Wang H, Zhang X, Fan X, Qian Y (2006) In situ bioelectrokinetic remediation of phenol-contaminated soil by use of an electrode matrix and a rotational operation mode. Chemosphere 64: 415-422.

115. Wu MZ, Reynolds DA, Fourie A, Thomas DG (2013) Optimal Field Approaches for Electrokinetic In Situ Oxidation Remediation. Groundwater Monitoring \& Remediation 33: 62-74.

116. Mattson ED, Bowman RS, Lindgren ER (2002) Electrokinetic ion transport through unsaturated soil: 2. Application to a heterogeneous field site. Journal of Contaminant Hydrology 54: 121-140. 